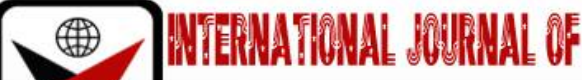

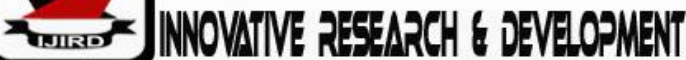

ISSN 2278-0211 (Online)

\section{Efficacy of Alligator Pepper (Aframomum Melegueta) L. Seed Powder against Maize Weevil (Sitophilus Zeamais) of Stored Maize}

Nwachukwu, M.o.
Lecturer, Department of Biology,
Federal University of Technology, Owerri, Imo State Nigeria
Azorji, J.N.
Lecturer, Department of Biological Sciences,
Hezekiah University, Umudi, Imo State Nigeria
Adjero, L.A.
Lecturer, Department of Biology,
Federal University of Technology, Owerri, Imo State Nigeria
Belonwu, A.C.
Student, Department of Biology,
Federal University of Technology, Owerri, Imo State Nigeria
Green, M.C.
Student, Department of Biology,
Federal University of Technology, Owerri, Imo State Nigeria
Akpovbovbo, D. P.
Student, Department of Biology,
Federal University of Technology, Owerri, Imo State, Nigeria

\section{Abstract:}

This study, 'efficacy of alligator pepper (Affromomum melegueta) seed powder against Sitophilus zeamais of stored maize' was conducted in the laboratory, Department of Biology, Federal University of Technology, Owerri between August and September, 2017. The experimental design used was completely randomized design (CRD) in four (4) replications with four treatments. The treatments were $0 \mathrm{~g}, 30 \mathrm{~g}, 60 \mathrm{~g}$, and $90 \mathrm{~g}$ of alligator pepper seed powder respectively. Seed powder of Affromomum melegueta was applied to different containers each containing $200 \mathrm{~g}$ of maize grains weighed using an electronic weighing balance in the laboratory at the rates $30 \mathrm{~g}, 60 \mathrm{~g}, 90 \mathrm{~g}$ respectively. The plastic white plates were shaken vigorously for optimum coverage of the grain surfaces. Seed powder of Affromomum melegueta was not applied to the control plate. Twenty-five (25) males and twenty-five (25) females of insect species Sitophilus zeamais was introduced into each plate containing the ground treatment powder and maize grain and the control. Each treatment and control were replicated three (3) times. The containers were covered with white netting material and held in place with rubber bands. The plastic containers were labeled respectively. After every forty-eight hours, the mortality of Sitophilus zeamais and other parameters in both treated and untreated plates were observed and recorded. The analysis of variance (ANOVA) showed that $90 \mathrm{~g}$ of alligator seed powder gave a significant reduction in mean number of holes, and average weight loss of maize seeds followed by $60 \mathrm{~g}, 30 \mathrm{~g}$, and $0 \mathrm{~g}$ of alligator pepper seed powder at $P=0.05$ level. The results also showed that the percentage mortality of Sitophilu szeamais was high in $90 \mathrm{~g}(90 \%)$ mortality than other treatments used. The phytochemical analysis conducted showed the presence of the alkaloids, tannins, flavonoids and saponins. These compounds were the active ingredients present in alligator pepper seeds and were able to control stored product pests. The findings therefore present satisfactory importance of Afromomum melegueta for stored pests' control as its administration increased Sitophilus zeamais mortality and reduced natality in high grams. Also, seeds damaged as a result of perforations by pests was significantly $(P=0.05)$ reduced, which as most probable, consequently led to a reduced seed weight loss in all the treated seeds.

Keywords: Bioinsecticides, Aframomum melegueta, maize weevil, control

\section{Introduction}

The maize weevil, Sitophilus zeamais Motschulsky (Coleoptera: Curculionidae) is a serious pest of stored maize, causing qualitative and quantitative losses. Bio-deterioration of stored grains, both marginal and comprehensive, has been 
traced to the activities of insect pests such as the maize weevils (Ewete \&Alamu, 1999; Rahman, et al., 2001). Post-harvest losses to storage insect pests such as the maize weevil have been recognized as an increasingly important problem in Africa (Markham et al., 1994). Cheap and effective methods for reducing S. zeamais damage are needed in these countries (Danho et al., 2002).

Corn is a staple food, and forms the bulk of cereal food for both children and adults. It is grown commercially and stored in Granaries and Silos. Unfortunately, due to the bio activities of weevils, farmers and corn dealers do suffer losses from time to time and from season to season (Rahman et al., 2001). Infestation by this weevil commences in the field (Demissie et al., 2008), but most damage is done during storage. Damaged grains have reduced nutritional values, low percent germination and reduced weight and market values, respectively. In other to address these losses, farmers had resorted to the use of chemical insecticidal pesticides (El-Atta \&Ahmed, 2002). However, these chemicals have attendant hazards like low affordability, resistance, environmental pollution, and other bio-hazards (UNEP,2002). The application of botanicals, as alternative substitutes to the conventional chemical agents has been reported by researchers (Jahromi et al., 2012; Nwachukwu \& Okoro, 2013).

Maize is an important food crop grown commercially on a large scale and as a small garden crop throughout the world (Richard et al., 1994). Nearly one thousand species of insects have been found associated with stored products in various parts of the world (Gc, 2006). Many pests of stored maize are Coleopterans and the most destructive tropical species for maize belongs to the genus Sitophilus and Tribolium (Bello et al., 2000). The maize weevil, Sitophiluszeamais Mutschulsky is a serious and the most important pest of stored maize, causing considerable losses. Significant reduction in the viability of the grain is a common effect of infestation by Sitophilus species (Okiwelu et al., 1987). The weevil, Sitophiluszeamais Mutschulsky poses a serious threat to food security, particularly in developing countries.

Aframomum melegueta also known as alligator pepper (indigenous names include: atare in Yoruba, ose-oji in Igbo land, citta in Hausa) is used in Nigeria and some other parts of West Africa, as a spicy during entertainment and have a wide range of folkloric uses in traditional medicine. They are used as a remedy for treating stomach ache, diarrhoea and snakebite (Umukoro \& Ashorobi, 2007; Ilic et al., 2010). The seed extract has been evaluated for anti-nociceptive, antiulcer, antimicrobial, anti-inflammatory, anti-oxidant and sexual performance enhancing activities (Ilic et al., 2010; Onoja et al., 2014). This study therefore is aimed at determining the pesticidal efficacy and antifeedant potentials of seed powder of Aframomummelegueta.

\section{Materials and Methods}

\subsection{Study Area}

This research work was carried out in the Biology laboratory, School of Biological Sciences, Federal University of Technology, Owerri. The mean temperature of the laboratory ranges from $27^{\circ} \mathrm{C}-30^{\circ} \mathrm{C}$ and the mean relative humidity $81 \%$ $90 \%$. The Federal University of Technology Owerri lies between latitude $05^{\circ} 21^{\prime}$ and $05^{\circ} 42^{\prime} \mathrm{N}$ and longitude $07^{\circ} 48^{\prime}$ and $06^{\circ} 53^{\prime} \mathrm{E}$. Owerri consists of tropical rainforest zone with average annual rainfall distribution of 2,250-2800mm. This region produces many agricultural products.

\subsection{Experimental Materials}

The experiment was performed using the following materials: Maize grain, variety-Succharata (sweet corn), Alligator pepper (Affromomum meleguea), White plastic plates, Marking tape, Permanent marker, Insect species (Sitophilus zeamais), White netting material, Rubber band, Weighing balance, Thermometer and Hygrometer.

\subsection{Procurement of Alligator Pepper and Maize Grain}

The alligator pepper and maize grain used in this research project were procured from the National Root Crops Research Institute (NRCRI), Umudike located at Km 8, Ikot-Ekpene Road, Umudike Umuahia, Abia State Nigeria.

\subsection{Preparation of Alligator Pepper Powder}

Freshly harvested fruit of alligator pepper (Affromomum melegueta) procured were washed and the fruits were dehauled, the seed air dried for 30 (thirty) days and ground into powder using an electric blender into various grams of $30 \mathrm{~g}, 60 \mathrm{~g}$, and $90 \mathrm{~g}$ of alligator pepper powder and placed in air tight containers for use.

\subsection{Experimental Design}

This study adopted a completely randomized design (CRD) with one maize variety (succharata) and four (4) treatments and one (1) control group.

All experimental treatments were replicated four (4) times with the following treatments;

$\mathrm{T}_{0}=0 \mathrm{~g}$ control

$\mathrm{T}_{1}=30 \mathrm{~g}$ alligator pepper powder

$\mathrm{T}_{2}=60 \mathrm{~g}$ alligator pepper powder

$\mathrm{T}_{3}=90 \mathrm{~g}$ alligator pepper powder

\subsection{Experimental Procedure}

Seed powder of Affromomum melegueta was applied to different containers each containing $200 \mathrm{~g}$ of maize grains weighed using an electronic weighing balance in the laboratory at the rates $30 \mathrm{~g}, 60 \mathrm{~g}, 90 \mathrm{~g}$ respectively. The plastic white plates were shaken vigorously for optimum coverage of the grain surfaces. Seed powder of Affromomum melegueta was 
not applied to the control plate. Twenty-five (25) males and twenty-five (25) females of insect species Sitophilus zeamais was introduced into each plate containing the ground treatment powder and maize grain and the control. Each treatment and control were replicated three (3) times. The containers were covered with white netting material and held in place with rubber bands. The plastic containers were labeled respectively. After every forty-eight hours, the mortality of Sitophilus zeamais in both treated plates were observed and recorded. The sexes of Sitophilus zeamais was determined by examining the snout. The snout of females is longer and thinner while that of males are shorter and fatter (Kranz et al., 1978). Also, females have smooth textured bodies while that of the males are rough (Kranz et al.,).

\subsection{Assessment Of Parameters}

\subsubsection{Number of Holes on Maize Grain}

The number of holes on maize grains were determined by counting the number of holes on the grain and the number of holes were recorded.

\subsubsection{Mortality Rate of Sitophilus Zeamais}

The mortality rate of Sitophilus zeamais was recorded at 1week, 2weeks, 3weeks, 4weeks, 5weeks, 6weeks, 7weeks, and 8weeks intervals by counting the number of dead Sitophiluszeamais.

\subsubsection{Weight Loss of Maize Grain}

The weight loss of maize grain was determined by measuring the initial weight of the maize grain before infestation minus the final weight of the maize grain after infestation by Sitophilus zeamais.

\subsubsection{Natality Rate of Sitophilus zeamais}

The adult Siophilus zeamais emergence of F1 progeny was observed in the control and treated grains. The number of F1 progeny was counted and recorded.

\subsection{Phytochemical Screening of Affromomum Melegueta}

\subsubsection{SEED}

The phytochemical tests for the identification of various classes of secondary metabolites was carried out using standard prescribed method of Trease and Evans (1999) and Edeoga et al., (2005).

\subsubsection{Statistical Analysis}

The data obtained were subjected to a one-way analysis of variance (ANOVA) procedure using SPSS version 20 and the effectiveness of the treatment means were compared using the least significant difference (LSD) test at P=0.05 level.

\section{Results}

\subsection{Alligator Pepper Seed Powder against Morality Rate of Sitophilus Zeamais (Maize Weevil)}

The mortality of Sitophilus zeamais showed significant difference when treated with $0 \mathrm{~g}, 30 \mathrm{~g}, 60 \mathrm{~g}$ and $90 \mathrm{~g}$ of alligator pepper seed powder. The $90 \mathrm{~g}$ alligator pepper seed powder had the highest mean number of mortality rate (dead weevils) at 1week, 2weeks,3weeks, 4weeks, 5weeks, 6weeks, 7weeks, and 8weeks after treatments with alligator pepper seed powder (Table1). The mean number of $S$. zeamais alive after treatments with alligator pepper seed powder showed that $0 \mathrm{~g}$ (control) recorded no deaths (50) of $S$. zeamais where there was no treatment application, followed by $30 \mathrm{~g}$ alligator pepper seed powder (17.2) and 60g (15.9) and the least was 90g alligator pepper seed powder (5.0) respectively.

\begin{tabular}{|c|c|c|c|c|c|c|c|c|c|c|}
\hline \multirow{2}{*}{$\begin{array}{c}\text { Alligator } \\
\text { pepper } \\
\text { seed powder } \\
\text { (g) } \\
\end{array}$} & \multirow{2}{*}{$\begin{array}{l}\text { Mean number } \\
\text { of weevils } \\
\text { introduced }\end{array}$} & \multicolumn{8}{|c|}{ Mean number of dead weevils in weeks } & \multirow{2}{*}{$\begin{array}{c}\text { Mean } \\
\text { number alive }\end{array}$} \\
\hline & & 1 & 2 & 3 & 4 & 5 & 6 & 7 & 8 & \\
\hline 0 & 50 & 0 & 0 & 0 & 0 & 0 & 0 & 0 & 0 & 50 \\
\hline 30 & 50 & 4.8 & 4.0 & 4.5 & 5.5 & 4.5 & 3.2 & 3.8 & 2.5 & 17.2 \\
\hline 60 & 50 & 5.3 & 4.5 & 4.5 & 6.3 & 5.3 & 4.5 & 2.5 & 2.0 & 15.9 \\
\hline 90 & 50 & 6.5 & 6.8 & 7.3 & 7.0 & 5.8 & 5.8 & 3.0 & 2.8 & 5.0 \\
\hline
\end{tabular}

Table 1: Effects of Alligator Pepper Seed Powder on Maize Weevil Mortality

\subsection{Number of Holes and Weight Loss of Maize Seeds}

The mean number of holes or damage on the maize seeds by $S$. zeamais at weekly intervals are recorded in mean (Table4. 2). From the result, there were significant differences $(\mathrm{P}=0.05)$. The control (84) showed a high increase in mean number of seed holes or damage followed by $30 \mathrm{~g}$ alligator pepper seed powder (43), and 60g alligator pepper powder (40) and the lowest was $90 \mathrm{~g}$ alligator pepper seed powder (15) respectively at probability of 0.05 level (Table 4 . 2). The 
mortality of $S$. zeamais showed that $0 \mathrm{~g}$ had 0 mean number of dead weevils with 0 percentage mortality, while $90 \mathrm{~g}$ alligator pepper seed powder had a significant high mean number of dead maize weevil (45.0) with the highest percentage mortality of $90 \%$. The $30 \mathrm{~g}$ and $60 \mathrm{~g}$ alligator pepper seed powders showed no significant difference at $\mathrm{P}=0.05$ level $($ Table 4.2). Similar trend showed in average weight loss of maize seeds and treated with $90 \mathrm{~g}$ alligator pepper seed powder (6.0g) gave the least average weight loss than other treatments used in the storage of maize seeds.

\begin{tabular}{|c|c|c|c|c|c|c|}
\hline $\begin{array}{l}\text { Alligator } \\
\text { Pepper }\end{array}$ & $\begin{array}{c}\text { Average } \\
\text { Initial } \\
\end{array}$ & $\begin{array}{c}\text { Average } \\
\text { Final } \\
\end{array}$ & Mean & Average & \multirow{2}{*}{$\begin{array}{c}\text { Mean } \\
\text { Number } \\
\text { Of Dead } \\
\text { Weevils }\end{array}$} & \multirow[t]{2}{*}{$\begin{array}{c}\text { Mortality } \\
\text { (\%) }\end{array}$} \\
\hline $\begin{array}{c}\text { seed } \\
\text { powder (g) }\end{array}$ & $\begin{array}{l}\text { weight of } \\
\text { maize (g) }\end{array}$ & $\begin{array}{l}\text { weight of } \\
\text { maize }(g)\end{array}$ & $\begin{array}{l}\text { number } \\
\text { of holes }\end{array}$ & $\begin{array}{l}\text { weight } \\
\text { loss (g) }\end{array}$ & & \\
\hline 0 & 200 & $168.5^{c}$ & $84^{a}$ & $31.5^{\mathrm{a}}$ & $0.0^{\mathrm{c}}$ & $0.0^{c}$ \\
\hline 30 & 200 & $184.0^{\mathrm{b}}$ & $43^{b}$ & $16.0^{b}$ & $32.5^{b}$ & $65.8^{b}$ \\
\hline 60 & 200 & $185.0^{\mathrm{b}}$ & $40^{b}$ & $15.0^{\mathrm{b}}$ & $34.1^{b}$ & $68.2^{b}$ \\
\hline 90 & 200 & $194.0^{a}$ & $15^{c}$ & $6.0^{c}$ & $45.0^{\mathrm{a}}$ & $90.0^{a}$ \\
\hline
\end{tabular}

Table 2: Effects of Alligator Pepper Seed Powder on number of holes and weight loss of maize seeds

Mean along the column having different letters of superscript differ significantly at $\mathrm{P}=0.05$ level

\subsection{Alligator Pepper Seed Powder against Natality Rate of Sitophilus Zeamais}

Table 4.3 showed the results on alligator pepper seed powder on natality rate of Sitophilus zeamais. The $0 \mathrm{~g}$ alligator pepper seed powder (15.5) gave the highest mean number of natality with $31.0 \%$ natality of $S$. zeamais, followed by $30 \mathrm{~g}$ alligator pepper seed powder (4.0) mean number of natality with $8.0 \%$ natality, $60 \mathrm{~g}$ alligator pepper seed powder (3.5) with $7.0 \%$ natality and $90 \mathrm{~g}$ alligator pepper seed powder (1.5) mean number of natality with $3.0 \%$ natality respectively.

\begin{tabular}{|c|c|c|}
\hline $\begin{array}{c}\text { Alligator } \\
\text { pepper seed powder (g) }\end{array}$ & $\begin{array}{c}\text { Mean number } \\
\text { of natality }\end{array}$ & Natality (\%) \\
\hline 0 & $15.5^{\mathrm{a}}$ & $31.0^{\mathrm{a}}$ \\
\hline 30 & $4.0^{\mathrm{b}}$ & $8.0^{\mathrm{b}}$ \\
\hline 60 & $3.5^{\mathrm{b}}$ & $7.0^{\mathrm{b}}$ \\
\hline 90 & $1.5^{\mathrm{c}}$ & $3.0^{\mathrm{c}}$ \\
\hline
\end{tabular}

Table 3: Effects of Alligator Pepper Seed Powder on Maize Weevil Natality (F1 progeny)

Mean along the column having different letters of superscript differ significantly at $\mathrm{P}=0.05$ level

\subsection{Proximate Composition And Phytochemical Analysis Of Alligator Pepper Seeds (Affromomum Melegueta)}

The proximate composition were dry matter (81.87\%), crude protein $(13.52 \%)$, crude fibre $(12.22 \%)$, ether extract (8.85\%), ash (8.15\%) and nitrogen free extract (49.10\%) while phytochemical results showed that alkaloid was present, tannin was strongly present, flavonoid was present and saponin was moderately resent (Table 4. 4 and 4. 5).

\begin{tabular}{|c|c|}
\hline Parameters (\%) & Affromomum Melegueta \\
\hline Dry mater & 81.87 \\
\hline Crude protein & 13.52 \\
\hline Crude fibre & 12.22 \\
\hline Ether extract & 8.85 \\
\hline Ash & 8.15 \\
\hline Nitrogen free extract & 49.1 \\
\hline Table 4: Proximate Composition of Affromomum Melegueta
\end{tabular}

\begin{tabular}{|c|c|}
\hline Parameters & Affromomum Melegueta \\
\hline Alkaloid & + \\
\hline Tannins & +++ \\
\hline Flavonoids & + \\
\hline Saponins & ++ \\
\hline
\end{tabular}

Table 5: Phytochemical Analysis of Affromomum melegueta

$$
\begin{aligned}
& +++=\text { Strongly present } \\
& ++=\text { Moderately present } \\
& +=\text { Present }
\end{aligned}
$$




\section{Discussion}

The effect of alligator pepper seed powder on weevil species has not been reported by many workers. This study showed significant high mortality and low natality of $S$. zeamais on the weevils treated with $90 \mathrm{~g}$ of alligator pepper seed powder and low mean number of holes (seed damage) than $60 \mathrm{~g}, 30 \mathrm{~g}$ and $0 \mathrm{~g}$ of alligator pepper seed powder. The potential for using tropical plants to control stored-product pests through repellency, immobilization or deterrent activity has been studied elsewhere.

The work of Ukeh et al., (2010) on behavioural responses of the maize weevil, Sitophilus zeamais, to host (storedgrain) and non-host plant volatiles at University of Aberdeen, Aberdeen, United Kingdom, explained, at least in part, how the application of these plants may protect grain from insect infestation in storage. The result of their study corroborates the underpinning science for the ethno-botanical use of plant powders to repel insects from stored products by resourcepoor farmers in West Africa and increase the potential practical value of using A. melegueta, Z. officinale and P. guineense for grain protection against $S$. zeamais infestation. The work of Adullahi et at., (2011) on studies on the efficacy of lime peel oil in protecting stored maize against adult maize weevils, Sitophilus Zeamais Bayero University, Kano, Nigeria, demonstrated that lime peel oil may be very potent because of the odour they produce and which may have exerted a toxic effect by disrupting normal respiratory activity of the weevils, thereby resulting in asphyxiation and subsequent death. They reported the toxicity bioassay efficacy of the lime peel oil on the maize weevils and that adult mortality significantly increased with increase in concentration and days of exposure. In addition, the work of Edelduok et al., (2012) on the bioinsecticidal potentials of testa powder of melon, Citrullus vulgaris Schrad for reducing infestation of maize grains by the maize weevil, Sitophilus zeamais at Akwa Ibom State University, Ikot Akpaden, Akwa Ibom State, Nigeria revealed that maize grains with testa powder of melon, Citrullus vulgaris at the dosage rates of $0.5 \mathrm{~g}$ to $3.0 \mathrm{~g}$ per $50 \mathrm{~g}$ of maize gave promising levels of control of Sitophilus zeamaiz in terms of reduction in the number of eggs laid and reduction in the number of offspring. The toxicity of the testa powder observed in their study could be attributable to colocynthin, a toxic poisonous substance known to be present in the white fleshy pulp of the melon fruit. However, from their result, the adult mortality of $S$. zeamais in the present study was not very high and not statistically significant.

Studies on the weevil's behavioural vis-à-vis plant extracts and powder treatments also emphasized their importance in the control of pest storage crop. Silva et at., (2013) work on the insecticide irritability of plant extracts against Sitophilus zeamais showed that behaviour avoidance of plant extract and permether in treated surface was recognized through the nine components used in the tests of insecticide irritability (that is, avoidance after contact).

However, the study demonstrated that the plant extract tested were effective against S. zeamais in stored maize with respect to insecticide irritability.

\section{Conclusion}

The present study evaluated the pesticidal potential of Afromomummelegueta on maize weevils, vis-à-vis their mortality and natality as well as ascertained the protective efficacy of the botanical against stored pest of maize. The findings therefore present satisfactory importance of Afromomummelegueta for stored pests' control as its administration increased Sitophiluszeamais mortality and reduced natality in high grams. Also, seeds damaged as a result of perforations by pests was significantly $(\mathrm{P}=0.05)$ reduced, which as most probable, consequently led to a reduced seed weight loss in all the treated seed

\section{Recommendations}

Given the need for more proactive measures and researches for the development of biopesticides for stored crops or agricultural products, the findings of this study therefore recommend the following:

- There is need for further research that will target using isolated bioactive compound of botanicals against the fertility genome or genetic makeup of common storage pests.

- There is need to seek out for botanicals with anti-oviposition and larvicidal efficacy to help break the life cycle and hinder development of the pest's metamorphic stages.

\section{References}

i. $\quad$ Ewete, F. K. \& Alamu, O. T. (1999). Extracts of three Mahogany species, as grain protectants

ii. Against Sitophilus zeamais Motschulsky (Coleoptera: Curculionidae). Journal of Tropical Forest Resources, 157 (5), $22-29$.

iii. Rahman, S. A., Agada, J. E.\& Idoko, O. J. (2001). Neem extract: the natural insecticides for

iv. profitable and sustainable cowpea production in Northern Nigeria. Journal of Agricultural Technology, 9 (1), 42 45.

v. Markham, R. H., Bosque-Perez, N., Borgemeister, C. \& Meikle, W. G. (1994). Developing pest management strategies for the maize weevil, Sitophilus zeamais, and the larger grain borer, Prostephanus truncatus, in the humid and sub-humid tropics.FAO Plant Protection Bulletin, 42, pp 97 - 116.

vi. Danho, M., Gaspar, C. \& Haubruge, E. (2002). The impact of grain quality on the biology of

vii. Sitophilus zeamais Motsch. (Coleoptera: Curculionidae) oviposition, distribution of eggs, adult emergence, body weight and sex ratio. Journal of Stored Products Research, 38 (3), 259 - 266.

viii. Demissie, G., Tefera, T. \& Tadesse, A. (2008). Importance of husk covering on field infestation of maize by SitophiluszeamaisMotsch. (Coleoptera: Curculionidea) at Bako, Western Ethiopia. African Journal of Biotechnology, 7 (2), $3774-3779$

ix. El-Atta, H. A. \& Ahmed, A. (2002). Comparative effect of some botanicals for the control of 
x. the seed weevil Carydoserratus (Oliver) (Coleoptera: Bruchidae). Journal of AppliedEntomology, 128 (10), 577 583.

xi. Jahromi, M. G., Pourmirza, A. A. \& Safaralizadeh, M. H. (2012). Repellent effects of sirino (garlic emulsion) against Lasioderma serricorne (Coleoptera: Anobiidae) and Triboliumcastaneum (Coleoptera: Tenebrionidae) by three laboratory methods. African Journal of Biotechnology, 11 (2), 280 - 288.

xii. Nwachukwu, M.O. \& Okoro, L.E. (2013). Effects of Citrus Sinensis (orange) powder peel extract on Cryptolests furuginens of pearl millet (Pennisetum glaucum) in Imo state. Journal of Technological Research.2 (2), 78-85

xiii. Gc, Y. D. (2006). Efficacy of indigenous plant materials and modified storage structures to insect pests of maize seed during on-farm storage. Journal of the Institute of Agriculture and Animal Science, 27 (2), 69 - 76.

xiv. Bello, G. D. Padina, S. Lastrab, C. L. \& Fabrizio, M. (2000). Laboratory evaluation and chemical biological control of rice weevil, Sitophilus oryzae L. in stored yam. Journal of Stored Products Research, 37 (6), 77 - 84.

xv. Okiwelu, S. N., Adu, O. O. \& Okankwo, V. N. (1987). The effect of Sitophilus zeamais (Motschulsky) (Coleoptera: Curculionidae) on the quality and viability of stored maize in Nigeria. Journal of Insect Science and its Application, $8,(4) 374-384$.

xvi. Umukoro, S.\& Ashorobi, R. B. (2007). Further studies on the antinociceptive action of aqueous seed extract of Aframomum melegueta. Journal of Ethnopharmacology, 109 (7)501 - 504.

xvii. Ilic, N., Schmidt, B. M., Poulev, A.\& Raskin, I. (2010). Toxicological evaluation of grain of

xviii. $\quad$ paradise (Aframomum melegueta) K. Schum. Journal of Ethnopharmacology, 127 (4), 352 - 356.

xix. Onoja, S. O., Omeh, Y. N., Ezeja, M. I. \& Chukwu, M. N. (2014). Evaluation of the in vitro and invivo antioxidant potentials of Aframomum melegueta methanolic seed extract. Journal of Tropical Medicine, Article ID 159343,6

xx. Ukeh, D. A., Birkett, M. A., Bruce, T. J. A., Allan, E. J., Pickett, J. A. \& Mordue, A. J. (2010). Behavioural responses of the maize weevil, Sitophilus zeamais, to host (stored-grain) and non-host plant volatiles. Journal Pest Management Science, $66(12) 44-50$.

xxi. Adullahi, N., Kabir, A. \& Yushau, M. (2011). Studies on the efficacy of lime peel oil in protecting stored maize against adult maize weevils, Sitophiluszeamais (Motschulsky). Journal of Entomology, 8(4), 398 - 403.

xxii. Edelduok, E., Akpabio, E., Eyo, J. \& Ekpe, E. (2012). Bio-insecticidal potentials of testa powder of melon, Citrullus vulgaris Schrad for reducing infestation of maize grains by the maize weevil, Sitophilus zeamais Motsch. Journal of Biology, Agriculture and Healthcare, 2 (8), 13 - 17.

xxiii. Silva, L. B., da Silva, J. C., Pavan, B. E., Pereira, F. F., Maggioni, K., Andrade, L. H., Candido, A. C. S. \& Peres, M. T. L. P. (2013). Insecticide irritability of plant extracts against Sitophilus zeamais. African Journal of Agricultural Research, $8(11), 978-983$. 